\title{
ORIENTAÇÕES PARA COLABORADORES
}

Espaço ameríndio propõe-se a ser uma revista científica eletrônica, com periodicidade semestral, vinculada ao Núcleo de Antropologia das Sociedades Indígenas e Tradicionais (NIT) do Programa de Pós-graduação em Antropologia Social da Universidade Federal do Rio Grande do Sul - UFRGS.

Nossa intenção central é a de promover o desenvolvimento da pesquisa sobre populações ameríndias, assim como colocar em evidência uma reflexão sobre os campos conceitual e metodológico da interface trans-disciplinar sobre a temática indígena americana.

\section{Espaço ameríndio tem por objetivos principais:}

1. divulgar a produção científica das mais diversas áreas relacionadas à temática ameríndia (Antropologia, Letras, Etno-história, Lingüística, História, Arqueologia, Etnoarqueologia, Arquitetura, Biologia, Ecologia, Educação, Saúde, Nutrição, Direito, Arte, entre outras);

2. cobrir uma lacuna existente no país quanto a periódicos transdisciplinares com abordagens na temática relacionada a populações indígenas americanas;

3. efetivar uma política de intercâmbio internacional, especialmente entre os países das três Américas.

Neste sentido, a composição da nominata do Conselho Editorial teve por finalidade refletir a abrangência destes variados e complementares olhares lançados sobre a temática indígena, através da escolha de profissionais relacionados a estas diversas áreas do conhecimento, com produção significativa na temática ameríndia, além de privilegiar a diversidade regional brasileira e internacional, no âmbito americano.

Espaço ameríndio tem como proposta a publicação de trabalhos inéditos na temática indígena americana, preocupando-se também em 
divulgar traduções de artigos e ensaios bibliográficos importantes já publicados em línguas que não a portuguesa e a espanhola.

Espaço ameríndio aceita colaborações nos seguintes formatos e normas:

6.1. A revista eletrônica publicará trabalhos inéditos (ou de relevância acadêmica, a critério do editor) sob a forma de artigos, ensaios bibliográficos e resenhas de livros, em português ou espanhol, ou, ainda, em inglês ou francês, condicionada à verificação da possibilidade de tradução;

6.2. Os artigos devem ter no máximo 10.000 palavras, incluindo referências bibliográficas e notas de rodapé;

6.3. Os ensaios bibliográficos devem ter no máximo 6.000 palavras, incluindo referências bibliográficas e notas de rodapé;

6.4. As resenhas deverão ser de livros que tragam importante contribuição para a área de estudos ameríndios e deverão conter até 2.000 palavras, incluindo notas de rodapé e referências;

6.5. Os artigos, ensaios bibliográficos e resenhas deverão ser enviados completos e revisados pelo autor em arquivo Word com a seguinte formatação: fonte Times New Roman, tamanho da letra (corpo) 12, espaçamento duplo, margem superior $3 \mathrm{~cm}$ e inferior de $2 \mathrm{~cm}$, margem esquerda $3 \mathrm{~cm}$ e direita $2 \mathrm{~cm}$, em papel A4; É RESPONSABILIDADE DO AUTOR A REVISÃO ORTOGRÁFICA/GRAMATICAL.

6.6. Os artigos e ensaios bibliográficos devem vir acompanhados de um resumo (em espaço simples), no mesmo idioma, de no máximo 120 palavras e mais quatro palavras-chave, além de uma versão em inglês do resumo (Abstract), nos mesmos padrões, com quatro palavras-chave (Keywords). A disposição deverá obedecer a seguinte ordem: Título do trabalho, nome do autor, instituição, resumo, palavras-chave, abstract e keywords;

6.7. Nos artigos, ensaios bibliográficos e resenhas as notas explicativas devem vir no rodapé da página (em números arábicos) e as referências devem vir após o texto, ordenadas alfabeticamente (conforme as normas vigentes da ABNT);

6.8. No corpo do texto as referências bibliográficas devem seguir o sistema "autor-data". A indicação de referência nas citações diretas deve 
trazer autor(es), ano de publicação e página(s) (AUTOR, Ano, página); nas citações indiretas a indicação de página é opcional (AUTOR, Ano, Página);

6.9. As citações diretas com mais de três linhas, no texto, devem ser destacadas com recuo de $4 \mathrm{~cm}$ à esquerda e corpo de letra 11 , sem aspas, em espaço simples; transcrições das falas dos informantes seguem a mesma norma. Ao final de cada citação indicar a referência (AUTOR, Ano, página[s]);

6.10. O recurso itálico deve ser utilizado em palavras estrangeiras, nos títulos (livros, eventos, etc.) e para dar ênfase. As "aspas duplas" são utilizadas em citações diretas com menos de três linhas (no corpo do texto), citações de palavras individuais ou palavras cuja conotação ou uso mereça destaque. Os recursos negrito e sublinhado devem ser evitados;

6.11. Imagens que façam parte do artigo (figuras e gráficos inclusive) devem ser enviadas em separado (como documento suplementar), numeradas na seqüência em que aparecem, em formato TIFF (sem compressão) e resolução de $300 \mathrm{dpi}$ no tamanho final pretendido para a impressão. Largura máxima: $12 \mathrm{~cm}$; altura máxima: $16 \mathrm{~cm}$ (ou 1417x1890 pixels). A localização exata das figuras/gráficos deve ser indicada no corpo do texto e indicadas as fontes (autores) em letra 11, com alinhamento centralizado;

6.12. Demais regras de formatação devem seguir as normas da ABNT (disponível em www.firb.br/abntmonograf.htm );

6.13. O autor, ao enviar seu trabalho, estará automaticamente concordando com a sua publicação;

6.14. Os trabalhos enviados para Espaço ameríndio serão submetidos a um parecerista ad hoc, que fundamentará a decisão final do Conselho Editorial sobre a sua publicação. Os nomes dos pareceristas e dos autores permanecerão em anonimato durante o processo de submissão. 6.15. Só serão aceitas as submissões feitas através do endereço eletrônico da revista Espaço Ameríndio.

6.16. Contato com a Comissão Editorial Executiva: espacoamerindio@ufrgs.br 